\title{
Increased Pulmonary Neuroendocrine Cells with Bombesin-like Immunoreactivity in Adult Patients with Eosinophilic Granuloma
}

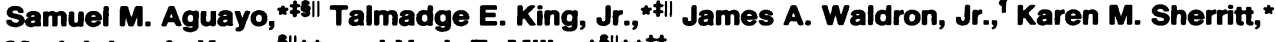 \\ Madeleine A. Kane, ${ }^{8 \| * *}$ and York E. Miller ${ }^{* ! 1 * * * \#}$ \\ ${ }^{*}$ Pulmonary Sciences Division, Department of Medicine, Veterans Administration Medical Center, Denver, Colorado 80220; ${ }^{\ddagger}$ National \\ Jewish Center for Immunology and Respiratory Medicine; ${ }^{\S}$ University of Colorado Cancer Center; "University of Colorado Health \\ Sciences Center; 'Veterans Administration Medical Center, University of Arkansas for Medical Sciences; ${ }^{* *}$ Medical Oncology \\ Division, Veterans Administration Medical Center; and ${ }^{\ddagger \ddagger}$ Eleanor Roosevelt Institute for Cancer Research, Denver, Colorado 80220
}

\section{Abstract}

Cigarette smoking is associated with hyperplasia of pulmonary neuroendocrine cells and variably increased levels of bombesin-like peptides in the lower respiratory tract. Because the neuropeptide bombesin is a chemoattractant for monocytes and a mitogen for $3 \mathrm{~T} 3$ fibroblasts, we hypothesized that an excess of neuroendocrine cells and bombesin-like peptides could contribute to lung inflammation and fibrosis in certain cigarette smokers.

Eosinophilic granuloma is a fibrotic lung disease of unknown etiology that in adults occurs almost invariably in cigarette smokers. We quantitated neuroendocrine cells with bombesin-like immunoreactivity in open lung biopsies from patients with eosinophilic granuloma $(n=6)$ and compared these with cigarette smokers $(n=6)$ who underwent lung resection for reasons other than primary lung disease. In addition, we compared them with patients with idiopathic pulmonary fibrosis $(n=8)$, a disease not associated with cigarette smoking. Finally, we also examined the mitogenic effect of bombesin on cultured human adult lung fibroblasts.

The patients with eosinophilic granuloma exhibited a 10fold increase in neuroendocrine cells with bombesin-like immunoreactivity compared to both smokers $(P=0.005)$ and patients with idiopathic pulmonary fibrosis $(P=0.005)$. In addition, bombesin produced a significant mitogenic effect on cultured human adult lung fibroblasts at concentrations of 1 nM and above. We conclude that increased numbers of pulmonary neuroendocrine cells with bombesin-like immunoreactivity are commonly found in patients with eosinophilic granuloma and, since bombesin-like peptides are chemotactic for monocytes and mitogenic for human lung fibroblasts, we speculate that neuroendocrine cell hyperplasia may be important in the pathogenesis of eosinophilic granuloma in adult cigarette smokers. (J. Clin. Invest. 1990. 86:838-844.) Key words: bombesin-like peptides $\bullet$ growth factors $\bullet$ fibroblasts $\bullet$ histiocytosis $\mathbf{X} \cdot$ cigarette smoking

Presented in part at the Annual Meeting of the American Thoracic Society 20-24 May 1990 (Am. Rev. Respir. Dis. [Abstr.] 141:4 [Suppl. 872]).

K. Sheritt's present address is University of Pennsylvania School of Medicine, Philadelphia, PA. Address reprint requests to Dr. Samuel M. Aguayo, Respiratory Care (111A), Denver Veterans Administration Medical Center, 1055 Clermont Street, Denver, CO 80220.

Received for publication 2 February 1990 and in revised form 11 April 1990.

The Journal of Clinical Investigation, Inc.

Volume 86, September 1990, 838-844

\section{Introduction}

We have reported that cigarette smoking is associated with markedly increased levels of bombesin-like peptides (BLP) ${ }^{1}$ in the lower respiratory tract of some individuals (1). BLP is the name given to the family of peptides having carboxy-terminal homology with the structure of bombesin, a tetradecapeptide originally isolated by Erspamer from the skin of the amphibian Bombina bombina $(2,3)$. These include gastrin-releasing peptide (GRP) and neuromedin B, the only BLP fully characterized in humans (4). In susceptible subjects, the increased levels of BLP in the lower respiratory tract are presumably due to a smoking induced hyperplasia of pulmonary neuroendocrine (NE) cells. Such a relationship has been demonstrated in an animal model by Tabassian and colleagues (5). Furthermore, BLP have been reported to be chemotactic for monocytes (6) and mitogenic for 3T3 fibroblasts (7). Thus, we hypothesized that an excess of NE cells and BLP could contribute to lung inflammation and fibrosis in susceptible cigarette smokers who demonstrate the greatest degree of NE cell hyperplasia.

Eosinophilic granuloma (EG) of the lung, also known as pulmonary histiocytosis $\mathrm{X}$ or Langerhans' cell granulomatosis $(8-10)$, is a fibrotic disorder of the lower respiratory tract. Although the pathogenesis of EG is unknown, an abnormal accumulation of mononuclear phagocytes and Langerhans' cells is thought to play a major role (11). However, the mechanisms modulating the increase in the numbers of alveolar macrophages and Langerhans' cells in the lungs remain to be elucidated. Interestingly, in adults, EG occurs almost invariably in current or former cigarette smokers (12). This suggests that cigarette smoke may play an important role in the pathogenesis of EG.

The purpose of this study was to determine whether open lung biopsies from patients with EG have increased NE cells with bombesin-like immunoreactivity when compared to normal cigarette smokers who underwent lung resection for reasons other than primary lung disease. In addition, we compared the EG patients to patients with idiopathic pulmonary fibrosis (IPF), a disease in which lung inflammation and fibrosis is not associated with cigarette smoking. Finally, we tested whether bombesin is mitogenic for human adult lung fibroblasts, thus providing a potential direct link between pulmonary NE cells, BLP, and the pathogenesis of EG.

1. Abbreviations used in this paper: $\mathrm{BAL}$, bronchoalveolar lavage; BLP, bombesin-like peptides; EG, eosinophilic granuloma; GRP, gastrinreleasing peptides; IPF, idiopathic pulmonary fibrosis; NE, neuroendocrine. 


\begin{tabular}{|c|c|c|c|c|c|c|c|c|}
\hline \multirow[b]{2}{*}{$\begin{array}{l}\text { Subject } \\
\text { No. }\end{array}$} & \multirow[b]{2}{*}{ Age } & \multirow[b]{2}{*}{ Smoking history } & \multirow[b]{2}{*}{ Diagnosis } & \multirow[b]{2}{*}{$\begin{array}{l}\text { BLP in } \\
\text { BAL fluid }\end{array}$} & \multicolumn{3}{|c|}{ Tissue examined } & \multirow{2}{*}{$\begin{array}{c}\text { NE cells } \\
\text { (per } 10 \mathrm{~cm} \text { of } \\
\text { airway length) }\end{array}$} \\
\hline & & & & & Slides & Airways & $\begin{array}{l}\text { Airway } \\
\text { length }\end{array}$ & \\
\hline & $y r$ & $p k / y r$ & & $\mathrm{pmol} / \mathrm{ml}$ & & & $m m$ & \\
\hline 1 & 22 & 6 & EG & 42 & 7 & 51 & 313 & 98.12 \\
\hline 2 & 30 & 10 & EG & 16 & 5 & 25 & 304 & 36.00 \\
\hline 3 & 32 & 20 & EG & 22 & 5 & 41 & 950 & 195.00 \\
\hline 4 & 29 & 10 & EG & 12 & 11 & 92 & 1,280 & 127.50 \\
\hline 5 & 58 & 92 & EG & $\mathrm{ND}^{*}$ & 7 & 36 & 791 & 18.33 \\
\hline 6 & 31 & 13 & EG & 6 & 7 & 49 & 982 & 20.00 \\
\hline 7 & 67 & Never smoked & IPF & $\mathrm{ND}^{*}$ & 4 & 15 & 146 & $\mathrm{ND}^{\ddagger}$ \\
\hline 8 & 55 & 45 , stopped 5 yr ago & IPF & 0.63 & 6 & 24 & 272 & 3.00 \\
\hline 9 & 43 & Never smoked & IPF & 12 & 7 & 31 & 209 & 53.00 \\
\hline 10 & 62 & 9, stopped 18 yr ago & IPF & $\mathrm{ND}^{*}$ & 5 & 10 & 109 & $\mathrm{ND}^{\ddagger}$ \\
\hline 11 & 72 & Never smoked & IPF & $\mathrm{ND}^{*}$ & 5 & 15 & 120 & $\mathrm{ND}^{\ddagger}$ \\
\hline 12 & 65 & 22, stopped 25 yr ago & IPF & 72 & 4 & 5 & 64 & 6.30 \\
\hline 13 & 47 & 66 & IPF & 18 & 4 & 8 & 68 & $\mathrm{ND}^{\ddagger}$ \\
\hline 14 & 67 & 51, stopped 22 yr ago & IPF & 8 & 5 & 12 & 132 & 4.66 \\
\hline
\end{tabular}

* ND, nondetectable; for statistical purposes, equal $0.2 ;{ }^{\ddagger}$ Nondetectable; for statistical purposes, equal 0 .

\section{Methods}

Subjects. Lung tissue samples were obtained by open lung biopsy from patients enrolled in the National Heart, Lung, and Blood Interstitial Lung Diseases Specialized Centers of Research program, the Denver Veterans Administration Medical Center, AMI Presbyterian-St. Luke's Medical Center, and the University of Colorado Health Sciences Center Department of Pathology. The protocol was approved by the Institutional Human Subjects Review Committee.

Six previously untreated patients with EG (three men, three women; mean age of $34 \mathrm{yr}$; range, 22-58 yr) were evaluated (Table I). All patients were current smokers and had symptoms of dyspnea and/ or cough and demonstrated chest radiographic abnormalities. None had extrapulmonary manifestations of EG. The diagnosis was based on previously described clinical, radiographic, and pathological criteria $(8,9)$.

Six biopsies were obtained from patients undergoing lung resection for reasons other than a primary lung disorder, including two lung transplant donors (Table II). Only open lung biopsies were utilized for this control group in order to avoid possible loss of immunoreactivity in devitalized tissue obtained at necropsy. This control group was composed of five men and one woman with a mean age of $40 \mathrm{yr}$; range, $16-68 \mathrm{yr}$. All were current smokers.

The IPF control group consisted of eight untreated patients (seven men, one woman; mean age of $60 \mathrm{yr}$; range, 43-72 yr). There were three never smokers, four former smokers, and only one current smoker (Table I). IPF was diagnosed on the basis of a compatible history, physical examination, chest radiograph, pulmonary physiologic evaluation, and a confirmatory open lung biopsy (13). None of the patients had evidence of a connective tissue disease, hypersensitivity pneumonitis, left ventricular dysfunction, cardiac valvular disease, or significant occupational exposures.

Open lung biopsies in patients with EG and IPF were obtained from two different lobes, generally the upper and lower lobe of the same lung, with avoidance of the tip of the lingula or middle lobe. In all instances, the surgeon attempted to sample portions of lung which were obviously affected, but not severely scarred. Biopsies from patients without primary lung disease (including lung cancer) were usually wedge resections of a solitary pulmonary nodule. All tissue was collected, fixed, and stained in a similar fashion. The tissue was fixed in

Table II. Characteristics of Cigarette Smokers who Underwent Lung Resection

\begin{tabular}{|c|c|c|c|c|c|c|c|}
\hline \multirow[b]{2}{*}{$\begin{array}{l}\text { Subject } \\
\text { No. }\end{array}$} & \multirow[b]{2}{*}{ Age } & \multirow[b]{2}{*}{$\begin{array}{l}\text { Smoking } \\
\text { history }\end{array}$} & \multirow[b]{2}{*}{ Reason for lung resection } & \multicolumn{3}{|c|}{ Tissue examined } & \multirow{2}{*}{$\begin{array}{l}\text { NE cells } \\
\text { (per } 10 \mathrm{~cm} \text { of } \\
\text { airway length) }\end{array}$} \\
\hline & & & & Slides & Airways & $\begin{array}{l}\text { Airway } \\
\text { length }\end{array}$ & \\
\hline & $y r$ & $p k / y r$ & & & & $m m$ & \\
\hline 1 & 16 & 3 & Lung transplant donor & 3 & 15 & 258 & 16.50 \\
\hline 2 & 28 & 10 & Teratoma & 3 & 7 & 197 & $\mathrm{ND}^{*}$ \\
\hline 3 & 34 & 10 & Lung transplant donor & 3 & 6 & 243 & 8.10 \\
\hline 4 & 47 & 40 & Hamartoma & 3 & 25 & 325 & 3.33 \\
\hline 5 & 48 & 60 & Chronic pulmonary embolism & 3 & 39 & 396 & 10.00 \\
\hline 6 & 68 & 50 & Metastatic colon carcinoma & 3 & 16 & 291 & $\mathrm{ND}^{*}$ \\
\hline
\end{tabular}

* ND, nondetectable; for statistical purposes, equal 0. 
$10 \%$ neutral buffered formalin immediately and embedded in paraffin within $24 \mathrm{~h}$. Subsequently, it was cut into $4-\mu \mathrm{m}$ sections and mounted on glass slides. Multiple sections from each site, stained with Masson pentachrome and hematoxylin-eosin, were evaluated independently and the diagnoses were confirmed.

Immunohistochemistry. Before immunohistochemical staining, slides were deparaffinized by three 5-min xylene washes followed by three 10-min ethanol washes. Endogenous peroxidase was quenched by a 30-min incubation in methanol with $0.2 \% \mathrm{H}_{2} \mathrm{O}_{2}$. Slides were then incubated for $1 \mathrm{~h}$ in $0.3 \%$ Triton in PBS, rinsed in tap water, and then incubated for 30 minutes with $150 \mu \mathrm{l}$ normal goat serum. An equal volume $(150 \mu \mathrm{l})$ of the rabbit antibombesin antibody (Biogenex Laboratories, Dublin, CA), at a dilution of 1:800, was added to the slides before overnight incubation in a humidified chamber. Subsequently, slides were rinsed and incubated with $150 \mu \mathrm{l}$ of biotinylated goat antirabbit immunoglobulins (Vector Laboratories, Burlingame, CA) at a concentration of $20 \mu \mathrm{g} / \mathrm{ml}$. After washing three times, slides were incubated for $1 \mathrm{~h}$ with $150 \mu \mathrm{l}$ of $25 \mu \mathrm{g} / \mathrm{ml}$ avidin-peroxidase complex (Vector Laboratories). Slides were washed and the stain developed using $40 \mu \mathrm{g} / \mathrm{ml}$ diaminobenzidine and $0.01 \% \mathrm{H}_{2} \mathrm{O}_{2}$, rinsed, incubated for $5 \mathrm{~min}$ in $3 \% \mathrm{CuSO}_{4}$, then briefly counterstained with hematoxylin. To examine the specificity of staining with the primary antibody, working dilutions of antibombesin antiserum were preincubated with bombesin or neurotensin before overlaying on slides. Additional tissue sections were also stained with the antibombesin mAb BBC353 (1), as well as anticalcitonin antiserum (Biogenex) and antichromogranin $A$ $\mathrm{mAb}$ (Biogenex), to confirm NE cell presence and numbers.

Morphometry. The method used in the present study for quantification of NE cells is similar to that of Kleinerman and co-workers (14) which normalizes NE cells per length of airway epithelium. Thus, this morphometric method allows for comparisons between specimens with different numbers of airways and different lengths of airway epithelium. As slides were examined, each airway was marked and the airway lumen perimeter was measured using a computer-controlled electronic digitizer (Tektronic 4051; Tektronix, Inc., Beaverton, Oregon). The number of NE cells which exhibited bombesin-like immunoreactivity were counted and the results expressed as NE cells per $10 \mathrm{~cm}$ of airway epithelium.

Histologic changes in the biopsies from the patients with fibrosis were so impressive that these observations could not be performed blindly except for the specific diagnosis (i.e., EG versus IPF). Tables I and II include the amount of histologic material examined in each case.

$B A L$ fluid. All the patients with EG and IPF underwent bronchoscopy and bronchoalveolar lavage (BAL) before open lung biopsy. None of the normal smokers underwent BAL. The procedure was performed as previously described (1). Briefly, BAL fluid was collected after sequential instillation of four $60 \mathrm{ml}$ aliquots of sterile normal saline solution via fiberoptic bronchoscopy and immediately placed in ice water. The lavage was centrifuged at $800 \mathrm{~g}$ for $10 \mathrm{~min}$. Cell-free BAL fluid supernatants were preserved in a final concentration of $2 \mathrm{~N}$ acetic acid and stored at $-70^{\circ} \mathrm{C}$. $24 \mathrm{~h}$ before assay, 2-ml aliquots of BAL fluid were vacuum dried and reconstituted to $25 \%$ of the original volume with $0.05 \mathrm{M}$ Hepes buffer, pH 7.0, in HPLC-grade water.

$B L P$ immunoassay. BAL fluid BLP content was determined by a competition ELISA using the antibombesin mAb BBC353 (1). This antibody is specific for the minimal biologically active carboxy-terminal heptapeptide shared by all known BLP. The specific immunostaining that human lung NE cells demonstrate with the antibody BBC353 supports its utility for these studies and suggests that we are measuring NE cell derived BLP (1). Briefly, testing plates (Nunc-Immuno I; InterMed, Denmark) were incubated overnight at $4^{\circ} \mathrm{C}$ with $1 \mathrm{ys}^{3}$-bombesin $(50 \mathrm{ng} /$ well) and blocked with $0.05 \%$ Tween 20 in PBS for $2 \mathrm{~h}$ at $4^{\circ} \mathrm{C}$. After washing twice, standard concentrations of bombesin and unknown BAL fluid samples $(50 \mu \mathrm{l} /$ well $)$ were added to the wells and incubated for $1 \mathrm{~h}$ at room temperature with the antibombesin $\mathrm{mAb}$ BBC353 ( $50 \mu \mathrm{l}$ of a $50 \mathrm{ng} / \mathrm{ml}$ solution). Unbound BBC353 was removed by washing twice, and a 1:5,000 dilution of peroxidase- labeled goat anti-mouse serum (Kierkegaard-Perry, Gaithersburg, MD) was added to the plates for $1 \mathrm{~h}$. Unbound second antibody was removed by washing twice. The chromogenic substrate $2,2^{\prime}$-azinobis 3-ethylbenz-thiazoline sulfonic acid was added in $0.1 \mathrm{M}$ sodium citrate, $\mathrm{pH} 5.0$, with $0.001 \% \mathrm{H}_{2} \mathrm{O}_{2}$ and absorbance $(414 \mathrm{~nm})$ was determined after $30 \mathrm{~min}$. All the samples were analyzed in quadruplicate versus a standard bombesin control curve in each plate. The results were reported in picomoles of BLP per milliliter of BAL fluid.

Fibroblast growth curves. The human lung fibroblast CCL 210, derived from the normal lungs of a 20-yr-old Caucasian female who died of head injuries, was obtained from the American Type Culture Collection (Rockville, MD). Fibroblasts were seeded in Cell Wells (Corning, New York, NY), 24-well plates at a density of $0.2 \times 10^{4}$ cells/16-mm well, at their fourth passage, in MCDB 110 medium (Sigma Chemical Co., St. Louis, MO) supplemented with various concentrations of FCS, $100 \mathrm{U} / \mathrm{ml}$ penicillin, $100 \mu \mathrm{g} / \mathrm{ml}$ streptomycin, and $1 \mu \mathrm{g} / \mathrm{ml}$ amphotericin B. Viable cells were identified by Trypan blue exclusion and counted using a hemocytometer (Reichert Scientific Instruments, Buffalo, NY) at various time intervals after plating in the absence or presence of different concentrations of bombesin (Peninsula, Princeton, NJ). 12 wells were counted at each time point. The results were reported as viable cells per well.

Statistical analysis. All the results were expressed as mean values and SE (mean \pm SEM). Statistical analyses were performed by either two-tailed, unpaired $t$ test or by nonparametric methods using the Mann-Whitney Rank-Sum test, the Kruskal-Wallis test for multiple comparisons, and the Spearman Rank Correlation Coefficient (15).

\section{Results}

Immunohistochemistry. Immunostaining of lung tissue with the antibombesin antiserum revealed an intense specific staining of NE cells throughout the lungs, predominantly in the airways (Fig. 1). Both single NE cells and NE cell clusters, termed neuroepithelial bodies, were immunostained. Occasionally, individual NE cells were observed within the interstitium. NE cells with bombesin-like immunoreactivity were identified in every patient with EG. There were two normal cigarette smokers and four IPF patients without detectable immunoreactivity. Biopsies that exhibited numerous NE cells with bombesin-like immunoreactivity also demonstrated confirmatory staining of these immunoreactive cells with anticalcitonin antiserum, antichromogranin $\mathrm{A}$ and antibombesin BBC353 mAbs. Biopsies with few or no bombesin-immunoreactive NE cells displayed a similar pattern with these antibodies (data not shown). No other cells were demonstrated to stain. The staining was totally abolished when the primary antibombesin antibody was omitted or preincubated with 5 $\mu \mathrm{g} / \mathrm{ml}$ of bombesin, but not with the unrelated neuropeptide neurotensin at concentrations of 5 or $25 \mu \mathrm{g} / \mathrm{ml}$.

Morphometry. The patients with EG demonstrated a 10fold increase in single NE cells (Fig. 2) with bombesin-like immunoreactivity $(82.49 \pm 28.93 \mathrm{NE}$ cells/10 cm airway epithelial length) compared with both the normal smokers (6.32 $\pm 2.64, P=0.005$, Kruskal-Wallis test) and the patients with IPF $(8.37 \pm 6.44, P=0.005$, Kruskal-Wallis test). Our quantitative analysis, expressed as NE cells per airway epithelial length, refers to the single NE cells scattered along the airway basement membranes that were easily identifiable (Fig. 1). In some patients, particularly those with EG, there were rare areas where clusters of NE cells appeared to overlay what could have been the lumen of an obliterated airway. These areas were not amenable to quantitative analysis; thus, it is 


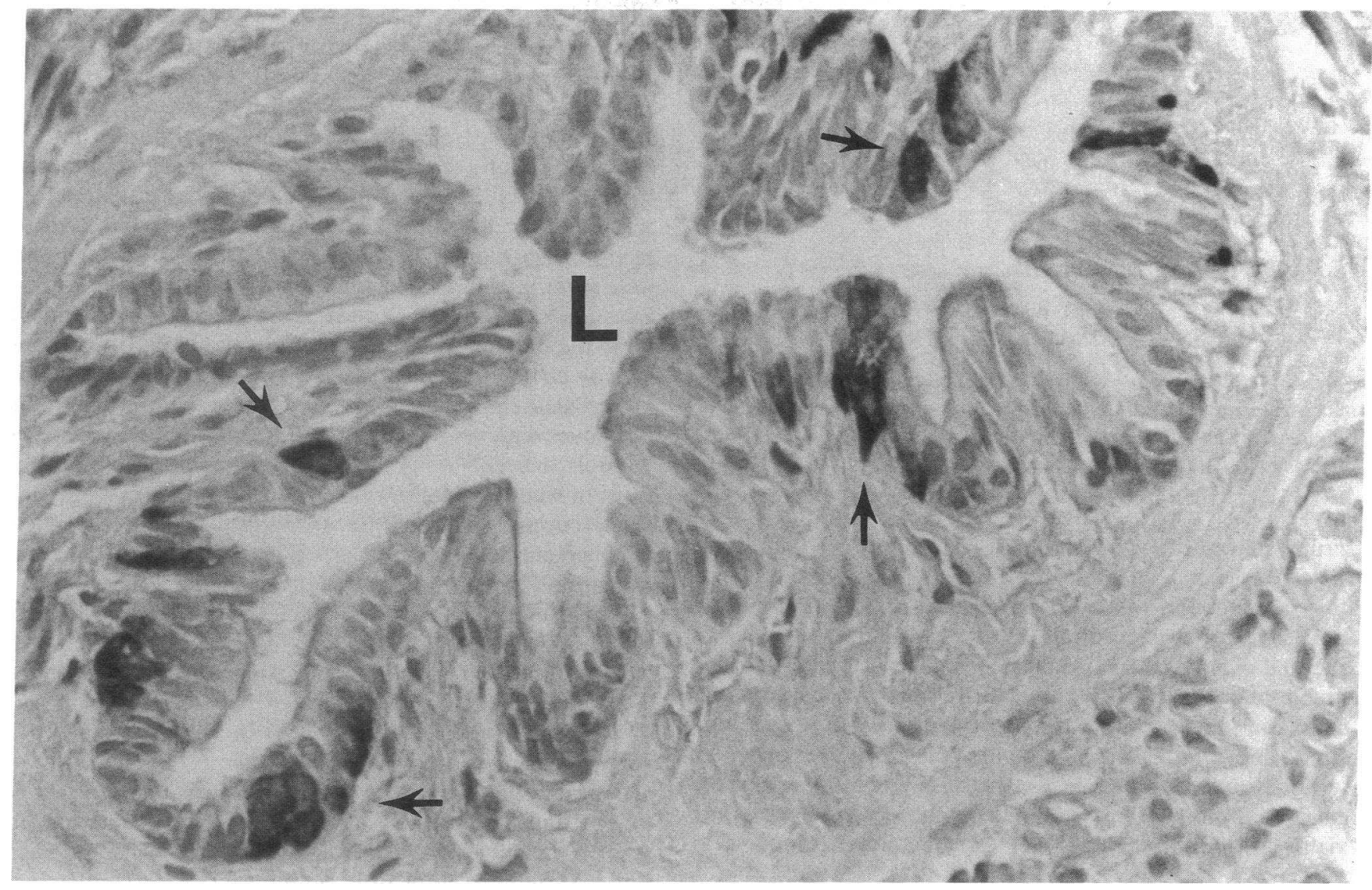

Figure 1. Neuroendocrine cells with bombesin-like immunoreactivity in a patient with eosinophilic granuloma. Indirect immunoperoxidase staining with antibombesin antiserum demonstrates numerous positive cells (arrows) along the basement membrane of a bronchiole. $L$, bronchiole lumen. $\times 400$.

likely that we may have underestimated the presence of immunoreactive cells in these cases. Neuroepithelial bodies, usually observed in areas of airway bifurcation, were rarely seen in the normal cigarette smokers, being more frequent in the patients with EG or IPF, as were single NE cells within the interstitium. Neuroepithelial bodies and single NE cells within the interstitium were not quantitated. The numbers of NE cells with bombesin-like immunoreactivity found in our group of normal smokers $(6.32 \pm 2.63 \mathrm{NE}$ cells $/ 10 \mathrm{~cm}$ airway epithelial length) did not differ from those reported in normal subjects $(6.9 \pm 2.5 \mathrm{NE}$ cells $/ 10 \mathrm{~cm}$ airway epithelial length) using anti-

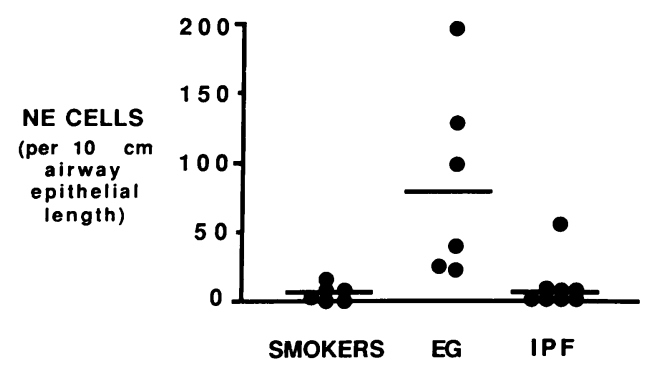

Figure 2. Neuroendocrine cells with bombesin-like immunoreactivity in normal cigarette smokers $(n=6)$, patients with eosinophilic granuloma (EG, $n=6$ ), and patients with idiopathic pulmonary fibrosis (IPF, $n=8$ ). Results expressed as number of positive cells per $10 \mathrm{~cm}$ of airway epithelial length. Horizontal bars represent mean values.
GRP immunohistochemistry and the same morphometric method $(16,17)$.

BLP levels. Detectable levels of BLP were present in the BAL fluid of five EG patients and five patients with IPF (Table I). In the EG patients, detectable BLP levels ranged from 6 to $42 \mathrm{pmol} / \mathrm{ml}$. In the IPF patients, detectable BLP levels ranged from 0.63 to $72 \mathrm{pmol} / \mathrm{ml}$. The four subjects with undetectable BLP levels were assigned the minimum detectable value of the ELISA $(0.2 \mathrm{pmol} / \mathrm{ml})$ for statistical purposes, resulting in a mean value for the EG patients of $16.33 \pm 6.01 \mathrm{pmol} / \mathrm{ml} \mathrm{com}$ pared with a mean of $13.83 \pm 8.66 \mathrm{pmol} / \mathrm{ml}$ for the IPF patients ( $P=$ NS, Mann-Whitney Rank-Sum test). There was no significant correlation between BAL fluid levels of BLP and numbers of NE cells found in the open lung biopsies from the EG patients $(r=0.71, P>0.10$, Spearman Rank Correlation Coefficient) or the patients with IPF ( $r=0.67, P>0.10$, Spearman Rank Correlation Coefficient). However, there was a marginal correlation $(r=0.58, P<0.05$, Spearman Rank Correlation Coefficient) between BAL fluid levels of BLP and open lung biopsy NE cells when both groups were analyzed together ( $n$ = 14).

Fibroblast growth curves. MCDB 110 is a medium that was developed for the propagation of human lung fibroblasts in minimal or serum-free conditions (18). Accordingly, serum stimulation of CCL 210 fibroblasts in MCDB 110 medium was maximal at FCS concentrations of $1 \%$ and above (data not shown). To examine the effect of bombesin on proliferation, a 


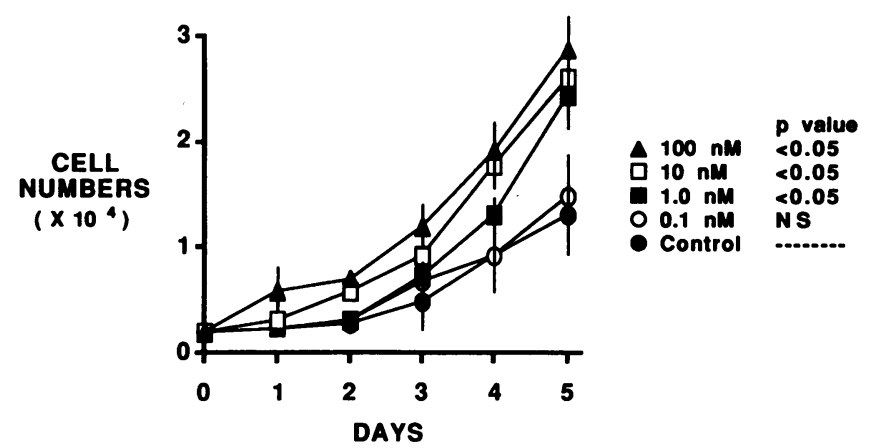

Figure 3. Growth curves for CCL 210 fibroblasts cultured with submaximal serum stimulation ( $0.5 \%$ FCS) and different concentrations of bombesin. The $P$ values refer to comparisons made after $5 \mathrm{~d}$. Vertical bars represent the standard error of the mean $(n=12)$.

serum concentration $(0.5 \%$ FCS $)$ which produced approximately half-maximal stimulation was used. Under these conditions, bombesin produced a significant mitogenic effect $(P$ $<0.05, t$ test) at concentrations of $1 \mathrm{nM}$ and above (Fig. 3) after $5 \mathrm{~d}$ of culture. Significant mitogenic effects were demonstrable at earlier time points with higher concentrations of bombesin (days $1-5$ with $100 \mathrm{nM}$, days 3-5 with $10 \mathrm{nM}$, and days 4 and 5 with $1 \mathrm{nM}$ ). In studies performed with maximal serum stimulation (1\% FCS), the addition of bombesin in concentrations of 10 and $100 \mathrm{nM}$ produced a $20 \%$ increase in viable cell numbers $(P<0.05, t$ test $)$ after $5 \mathrm{~d}$ of culture.

\section{Discussion}

In this study, we found that open lung biopsies from adult patients with EG have markedly increased numbers of NE cells with bombesin-like immunoreactivity compared with cigarette smokers and most patients with IPF. These findings are of interest because BLP have effects that are relevant to the pathophysiology of EG and these observations may help to delineate a novel pathogenetic scheme with potential therapeutic implications. In addition, these observations may provide a better understanding of the lung's response to cigarette smoke.

NE cells are prominent in human fetal lungs, where the BLP they produce are growth factors thought to be important for the paracrine regulation of lung growth and development $(19,20)$. As the rate of lung growth declines, the number of NE cells with BLP immunoreactivity starts to decrease during the neonatal period, and the low numbers seen in normal adult lungs are reached within the first decade of life (19-22). Prominent NE cells have been observed in bronchopulmonary dysplasia (23), cystic fibrosis (22), bronchiectasis (24), and other miscellaneous conditions (25). However, the role that the NE cells may play in these diseases remains speculative.

While NE cells contain a variety of other neuropeptides and mediators which may be important in lung development and disease (26), we have focused on BLP because they have physiologic effects, such as chemotaxis for monocytes (6) and mitogenesis for fibroblasts (7), which seem most obviously relevant to the pathogenesis of pulmonary fibrosis. To date, no studies have accurately defined the number of NE cells with bombesin-like immunoreactivity in open lung biopsies obtained from healthy, adult, nonsmoker lungs, presumably be- cause of the difficulty inherent in obtaining such lung tissue. However, Gosney and co-workers reported that NE cells were readily demonstrable and uniformly distributed in the lungs of 15 adults coming to necropsy within $18 \mathrm{~h}$ of their death, with no evidence of any appreciable pulmonary disease (16). Further, this group reported more recently that patients with chronic bronchitis and emphysema exhibited a twofold increase in NE cells with GRP immunoreactivity compared to a group of age-matched controls (17). Although these studies were performed in autopsy specimens, the results are useful in assessing our findings because the methods were identical. First, the number of NE cells with bombesin-like immunoreactivity observed in our normal cigarette smokers $(6.32 \pm 2.63$ $\mathrm{NE}$ cells $/ 10 \mathrm{~cm}$ airway epithelial length) does not differ from the values reported by Gosney and colleagues for their normal controls $(6.9 \pm 2.5 \mathrm{NE}$ cells $/ 10 \mathrm{~cm}$ airway epithelial length), most of whom were also smokers $(16,17$; Gosney, J. R., personal communication). Secondly, although it is unclear whether pulmonary NE cells are increased in smokers, and perhaps IPF patients, compared to nonsmokers, the number of NE cells in our patients with EG clearly exceeds that reported for smokers and thus suggests that hyperplasia of NE cells with bombesin-like immunoreactivity could play a role in the pathogenesis of EG.

Although significant differences in immunoreactive NE cells were demonstrated between the EG and IPF patients, no significant differences were observed in their BAL fluid levels of BLP. Furthermore, in this limited number of patients, there was no, or only weak, correlation between NE cell numbers and BAL fluid levels of BLP. Multiple factors, including rates of neuropeptide synthesis, secretion, and degradation, as well as technical factors which are inherent to each of these two sampling methods, may account for this discrepancy (27). Determining the clinical utility of each of these techniques of

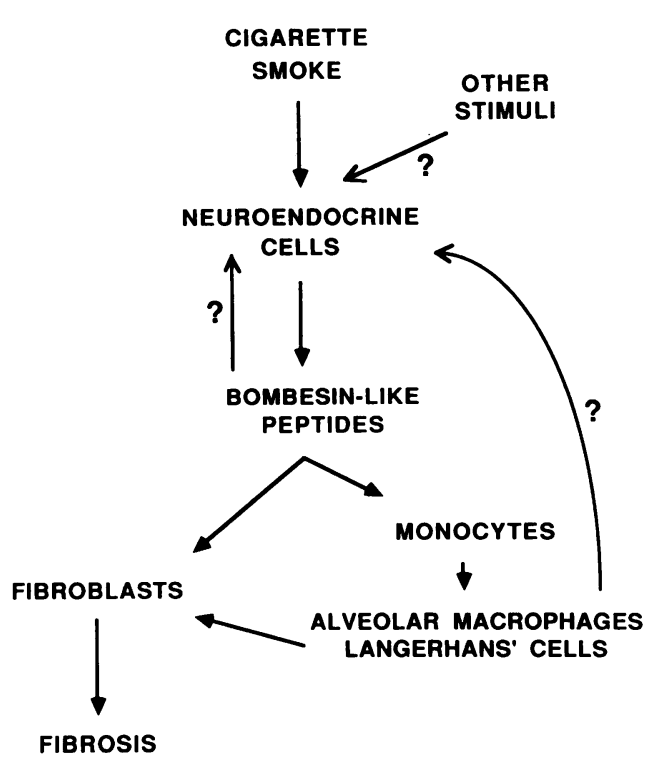

Figure 4. Hypothetical pathogenetic scheme demonstrating how cigarette smoke induced neuroendocrine cell hyperplasia may contribute to airway infiltration by mononuclear phagocytes and fibrosis in EG. In most smokers, the degree of NE cell hyperplasia demonstrated in EG does not occur. Presumably, either patients with EG are innately more susceptible to cigarette smoke or are exposed to other stimuli which interact synergistically to induce NE cell hyperplasia. 
assessing NE cell activity in the lung will require further investigation. Nonetheless, the significant differences observed in open lung biopsies suggest that paracrine effects of NE cell-derived peptides may be important in EG.

The mechanisms whereby pulmonary NE cells are stimulated to proliferate remain unknown but experimental models of NE cell hyperplasia suggest several possibilities. Hypoxia stimulates degranulation of NE cells in vivo (27), and appears to cause NE cell hyperplasia if sustained $(25,29)$. Asbestos fibers have been demonstrated to cause NE cell hyperplasia and increased bombesin-like immunoreactivity in an animal model $(30,31)$, as has exposure to cigarette smoke (5). Several investigators have also demonstrated an independent proliferative effect on NE cells from nicotine (32) and nitrosamines $(14,33)$. Thus, airway hypoxia, exposure to some irritants, and cigarette smoke may all induce, as well as interact additively or synergistically to induce, NE cell hyperplasia in various situations. The relatively low numbers of NE cells observed in most patients with IPF suggests that NE cell hyperplasia is not necessarily associated with all forms of lung inflammation. However, the possibility that different inflammatory mediators and growth factors may stimulate NE cell proliferation has not been investigated. Since there was no significant difference in smoking history between the control smokers, IPF patients, and patients with EG, and only one IPF patient, who was a nonsmoker, overlaps with the EG group, EG may be a disease in which there is an exaggerated response of NE cells to cigarette smoke and perhaps other stimuli. A greater understanding of genetic and environmental factors determining the NE cell response to cigarette smoke is needed to examine this hypothesis. Other potential amplification mechanisms worthy of investigation are interactions between inflammatory mediators and NE cells, and the possibility of autocrine growth stimulation for NE cells similar to that described for small cell lung carcinoma (34).

As depicted in Fig. 4, there are several potential roles for BLP in the pathogenesis of EG. First, alveolar macrophages and dendritic/Langerhans' cells are thought to be important effector cells in EG because, in addition to obvious tissue infiltration, these cells produce a number of cytokines which could transform quiescent lung fibroblasts into a profibrotic state $(11,35)$. Although the mechanism is unknown, cigarette smoke has an early effect on the number, distribution, and differentiated state of dendritic/Langerhans' cells in the human lung (36). Since BLP are chemoattractant for monocytes (6) and markedly increased levels of BLP are detected in the BAL fluid of some cigarette smokers (1), we propose a speculative pathogenetic scheme in which stimulation of NE cells by cigarette smoke in rare susceptible subjects may cause an exaggerated hyperplasia of NE cells with BLP immunoreactivity, increased recruitment of monocytes into the lungs, and perhaps enhancement of monocyte differentiation into dendritic/Langerhan's cells. Moreover, BLP have been demonstrated to be growth factors for normal human bronchial epithelial cells (37), and in this report we have also demonstrated that bombesin is mitogenic for human lung fibroblasts. Thus, BLP have effects on both mononuclear phagocytes and pulmonary cells which are potentially relevant to the processes of lung inflammation and fibrosis in EG.

In conclusion, we have found markedly increased numbers of NE cells with bombesin-like immunoreactivity in the open lung biopsies of patients with EG compared with normal ciga- rette smokers and most patients with IPF. Whether this NE cell hyperplasia is a cause or a result of disease remains unclear. However, it is attractive to consider that NE cell-derived mediators, such as BLP, have important paracrine effects that may contribute to pulmonary disease if inappropriately overproduced. These studies may also provide insight to the potential role of NE cells in other lung disorders.

\section{Acknowledgments}

We thank C. Welsh, D. P. White, J. Fisher, and M. I. Schwarz for helpful discussions; M. Wallace and W. S. Hammond for invaluable assistance in obtaining pathological specimens; $P$. Archer for statistical advice; and S. Y. Hansen for manuscript preparation.

Samuel M. Aguayo is a Robert Wood Johnson Foundation fellowship awardee (Minority Medical Faculty Development Program). This work was also supported by the National Institutes of Health grant R01 HL-29891, Minority Investigator Supplemental Research Award (S. M. Aguayo), National Cancer Institute First Award R29CA44763-01 (M. A. Kane), Specialized Centers of Research grant National Heart, Lung, and Blood Institute HL-27353 (T. E. King, Jr.) and by Veterans Administration Career Development and Merit Review grants (Y. E. Miller and M. A. Kane).

\section{References}

1. Aguayo, S. M., M. A. Kane, T. E. King, Jr., M. I. Schwarz, L. Grauer, and Y. E. Miller. 1989. Increased levels of bombesin-like peptides in the lower respiratory tract of asymptomatic cigarette smokers. J. Clin. Invest. 84:1105-1113.

2. Erspamer, V., and V. L. W. Go. 1988. Nomenclature Meeting. Ann. NY Acad. Sci. 547:1-2.

3. Erspamer, V., G. F. Erspamer, and M. Inselvini. 1970. Some pharmacological actions of alytesin and bombesin. J. Pharm. Pharmacol. 22:875-876.

4. Spindel, E. R., and I. M. Krane. 1988. Molecular biology of bombesin-like peptides. Comparison of cDNAs encoding human gastrin-releasing peptide, human neuromedin $\mathrm{B}$, and amphibian neurotensin. Ann. NY Acad. Sci. 547:10-20.

5. Tabassian, A. R., E. S. Nylen, R. I. Linnoila, R. H. Snider, M. M. Cassidy, and K. L. Becker. 1989. Stimulation of hamster pulmonary neuroendocrine cells and associated peptides by repeated exposure to cigarette smoke. Am. Rev. Respir. Dis. 140:436-440.

6. Ruff, M. R., E. Schiffman, V. Terranova, and C. B. Pert. 1985. Neuropeptides are chemoattractants for human tumor cells and monocytes: a possible mechanism for metastasis. Clin. Immunol. Immunopathol. 37:387-396.

7. Rozengurt, E., and J. Sinnett-Smith. 1983. Bombesin stimulation of DNA synthesis and cell division in cultures of Swiss 3T3 cells. Proc. Natl. Acad. Sci. USA. 80:2936-2940.

8. Auld, D. 1957. Pathology of eosinophilic granuloma of the lung. Arch. Pathol. 63:113-131.

9. Friedman, P. J., A. A. Liebow, and J. Sokoloff. 1981. Eosinophilic granuloma of lung: clinical aspects of primary pulmonary histiocytosis in the adult. Medicine (Baltimore). 6:385-396.

10. Basset, F., P. Soler, and A. J. Hance. 1986. The Langerhans' cell in human pathology. Ann. NY Acad. Sci. 465:324-339.

11. Crystal, R. G., P. B. Bitterman, S. I. Rennard, A. J. Hance, and B. A. Keogh. 1984. Interstitial lung diseases of unknown cause: disorders characterized by chronic inflammation of the lower respiratory tract. N. Engl. J. Med. 310:154-166, 235-244.

12. Hance, A. J., F. Basset, G. Saumon, C. Daniel, D. Valeyre, J. P. Battesti, J. Chretien, and R. Georges. 1986. Smoking and interstitial lung disease: the effect of cigarette smoking on the incidence of pulmonary histiocytosis $\mathrm{X}$ and sarcoidosis. Ann. NY Acad. Sci. 465:654-656.

13. Watters, L. C., M. I. Schwarz, R. M. Cherniack, J. A. Waldron, T. L. Dunn, R. E. Stanford, and T. E. King, Jr. 1987. Idiopathic 
pulmonary fibrosis: pretreatment bronchoalveolar lavage cellular constituents and their relationships with lung histopathology and clinical response to therapy. Am. Rev. Respir. Dis. 135:696-704.

14. Kleinerman, J., A. M. Marchevsky, and J. Thornton. 1981. Quantitative studies of APUD cells in airways of rats: the effects of diethylnitrosamine and $\mathrm{NO}_{2}$. Am. Rev. Respir. Dis. 124:458-462.

15. Siegel, S. 1956. Nonparametric Statistics for the Behavioral Sciences. McGraw-Hill Book Co., New York.

16. Gosney, J. R., M. C. J. Sissons, and R. D. Allibone. 1988. Neuroendocrine cell populations in normal human lungs: a quantitative study. Thorax. 43:878-882.

17. Gosney, J. R., M. C. J. Sissons, R. D. Allibone, and A. F. Blakey. 1989. Pulmonary endocrine cells in chronic bronchitis and emphysema. J. Pathol. 157:127-133.

18. Bettger, W. G., S. T. Boyce, B. J. Walthall, and R. G. Ham. 1981. Rapid clonal growth and serial passage of human diploid fibroblasts in a lipid-enriched synthetic medium supplemented with epidermal growth factor, insulin, and dexamethasone. Proc. Natl. Acad. Sci. USA. 78:5588-5592.

19. Spindel, E. R., M. E. Sunday, H. Hofler, H. J. Wolfe, J. F. Habener, and W. W. Chin. 1987. Transient elevation of messenger RNA encoding gastrin releasing peptide, a putative pulmonary growth factor in human fetal lung. J. Clin. Invest. 80:1172-1179.

20. Sunday, M. E., L. M. Kaplan, E. Motoyama, W. W. Chin, and E. R. Spindel. 1988. Gastrin-releasing peptide (mammalian bombesin) gene expression in health and disease. Lab. Invest. 59:5-24.

21. Wharton, J., J. M. Polak, S. R. Bloom, M. A. Ghatei, E. Solcia, M. R. Brown, and A. G. E. Pearse. 1978. Bombesin-like immunoreactivity in the lung. Nature (Lond.). 273:769-770.

22. Johnson, D. E., J. D. Wobken, and B. G. Landrum. 1988. Changes in bombesin, calcitonin, and serotonin immunoreactive pulmonary neuroendocrine cells in cystic fibrosis and after prolonged mechanical ventilation. Am. Rev. Respir. Dis. 137:123-131.

23. Johnson, D. E., J. E. Lock, R. P. Elde, and T. R. Thompson. 1982. Pulmonary neuroendocrine cells in hyaline membrane disease and bronchopulmonary dysplasia. Pediatr. Res. 16:446-454.

24. Cunningham, G. J., E. Massau, and J. B. Walter. 1958. The frequency of tumor-like formations in bronchiectatic lungs. Thorax. 13:64-68

25. Gould, V. E., R. I. Linnoila, V. A. Memoli, and W. H. Warren. 1983. Neuroendocrine components of the bronchopulmonary tract: hyperplasias, dysplasias, and neoplasms. Lab. Invest. 49:519-537.
26. Aguayo, S. M., and Y. E. Miller. 1989. Neuropeptides in inflammation and tissue repair. In Handbook of Inflammation. Vol. 6: Mediators of Inflammatory Process. P. M. Henson and R. D. Murphy, editors. Elsevier/North Holland, Amsterdam. 1-28.

27. Reynolds, H. Y. 1987. Bronchoalveolar lavage. State of the art. Am. Rev. Respir. Dis. 135:250-263.

28. Lauweryns, J. M., M. Cokelaere, M. Deleersnyder, and M. Liebens. 1977. Intrapulmonary neuro-epithelial bodies in newborn rabbits: influence of hypoxia, hyperoxia, hypercarbia, nicotine, reserpine, L-DOPA, and 5-HTP. Cell Tissue Res. 182:425-440.

29. Taylor, W. 1977. Pulmonary argyrophil cells at high altitude. $J$. Pathol. 122:137-144.

30. Johnson, N. F., J. C. Wagner, and H. A. Wills. 1980. Endocrine cell proliferation in the rat lung following asbestos inhalation. Lung. 158:221-228.

31. Day, R., I. Lemaire, S. Masse, and S. Lemaire. 1985. Pulmonary bombesin in experimentally induced asbestosis in rats. Exp. Lung Res. 8:1-13.

32. Wang, N., M. Chen, and D. E. Schraufnagel. 1984. The cumulative scanning electron microscopic changes in baby mouse lungs following prenatal and postnatal exposures to nicotine. J. Pathol. 144:89-100.

33. Reznik-Schuller, H. 1976. Ultrastructural alterations of APUD cells during nitrosamine-induced lung carcinogenesis. J. Pathol. 121:789-792

34. Cuttitta, F., D. N. Carney, J. Mulshine, T. W. Moody, J. Fedorko, A. Fishler, and J. D. Minna. 1985. Bombesin-like peptides can function as autocrine growth factors in human small cell lung cancer. Nature (Lond.). 316:823-826.

35. Rennard, S. I., P. B. Bitterman, W. B. Davis, M. Spatafora, J. Given, S. Saltzman, B. A. Keogh, and R. G. Crystal. 1983. Destruction and fibrosis of the lung parenchyma in adult pulmonary histiocytosis $\mathrm{X}$ is mediated by alveolar mononuclear phagocytes. Clin. Res. 31:420A. (Abstr.)

36. Soler, P., A. Moreau, F. Basset, and A. J. Hance. 1989. Cigarette smoking-induced changes in the number and differentiated state of pulmonary dendritic cells/Langerhans' cells. Am. Rev. Respir. Dis. 139:1112-1117.

37. Willey, J. C., J. F. Lechner, and C. C. Harris. 1984. Bombesin and the C-terminal tetradecapeptide of gastrin-releasing peptide are growth factors for normal human bronchial epithelial cells. Exp. Cell Res. 153:245-248. 